\title{
АНГЛИЦИЗМИ У ЖАРГОНУ ЈУГОИСТОЧНЕ СРБИЈЕ
}

Предмет рада је превасходно семантичко/садржинско и формално/обличко поређење англицизама у жаргону југоисточне Србије са енглеским лексемама од којих су настали. Анализирани англицизми ексцерпирани су из Речника жаргонизама јужне пруге, а циљ је да испитамо 1) колико се опсег значења англицизама у жаргону југоисточне Србије променио у односу на конкретне енглеске лексеме; 2) на које начине су се анализирани англицизми формално уклопили у морфолошки систем српског језика. Једна група анализираних примера има иста значења као и одговарајуће енглеске речи (фан, фејк, хејm, фенси итд.). Са друге стране су лексеме енглеског порекла са промењеним значењем у жаргону југоисточне Србије: контејнер „велики и неисправан аутомобил”, оскар ,јединица као оцена”, монокл „модрица око очне јабучице”, матрикс „математика” итд. Тенденција ка учешћу англицизама у творби речи значајна је јер показује морфолошко понашање адаптираних англицизама и висок ниво уклопљености у српски језик (нпр. искулирати, забаговати).

Кључне речи: жаргонизми, англииизми, енглески модел, српска реплика, југоисточна Србија, модификовање значења, садржина, форма.

\section{1. Увод}

Англицизми чине део лексике страног порекла у стандардном српском језику, али су и саставни део жаргона. Грађа за овај рад ексцерпирана је из Речника жаргонизама јужне пруге Јордане Марковић и Татјане Трајковић, при чему ексцерпирани англицизми чине око $5 \%$ грађе овог речника жаргона. Превасходно су у анализираној грађи именице, глаголи и придеви. У овом раду се енглески модели и српске реплике пореде семантички/ садржински и формално/облички, а циљ је да испитамо: 1) колико се опсег значења англицизама у жаргону југоисточне Србије променио у односу на

\footnotetext{
${ }^{1}$ aleksandra.janic@filfak.ni.ac.rs

2 Припремљено у оквиру интерног пројекта Срйски језик некад и сад: тингввисиичка исйраживань (360/1-16-10-01), који се изводи на Филозофском факултету у Нишу. Ово истраживање финансијски је подржало Министарство просвете, науке и технолошког развоја Републике Србије.
} 
конкретне енглеске речи; 2) на које начине су се анализирани англицизми уклопили у морфолошки систем српског језика.

У вези са семантиком англицизама у жаргону југоисточне Србије, са једне стране су примери који имају иста значења као и одговарајуће енглеске лексеме (попут фан „обожавалац”, фејк „лажан”, фенси „који је леп, префињен”, хејm „мржња”). Са друге стране су англицизми чије значење је модификовано у жаргону југоисточне Србије у односу на оригинално значење у енглеском, попут: контејнер „велики и неисправан аутомобил”, оскар ,јединица као оцена”, монокл „модрица око очне јабучице”. Оваквим и сличним примерима, њиховим значењским нијансама, уз осврт на њихов творбени потенцијал, те поређењем са одговарајућим енглеским лексемама - бавимо се у наставку рада. Конкретније, бавићемо се формалном и садржинском кореспондентношћу српских реплика и енглеских модела према типологији Твртка Прћића (2012).

Структура рада је следећа: У другом одељку дајемо теоријске основе о жаргонизмима и англицизмима у српском језику, у трећем се бавимо англицизмима чије се значење није променило у жаргону југосточне Србије у односу на значење одговарајућих енглеских лексема, уз осврт на формалну кореспондентност српских реплика и енглеских модела, те на фонолошко-морфолошку адаптацију у српском и творбене елементе. Англицизмима чије се значење модификовало у односу на оригинално значење одговарајућих енглеских лексема и формалном кореспондентношћу српских реплика и енглеских модела бавимо се у четвртом одељку. Пети одељак садржи закључак рада.

\section{2. Теоријски основи о жаргону и англицизмима}

Иако се у великом броју радова бавио жаргоном, Ранко Бугарски (2004б: 81) наводи да појам жаргона изазива бројне недоумице међу лаицима и стручњацима управо због неодређености, двосмислености и противречности. Суштину жаргона и разлог његовог постојања Бугарски (20046: 82) види у потреби „чланова неке друштвене групе да и специфичним вербалним средствима афирмишу свој идентитет и потврде своју припадност датој групи”. Стога се жаргоном може назвати „сваки неформални и претежно говорни варијетет неког језика који служи за идентификацију и комуникацију унутар неке друштвено одређене групе - по професији, социјалном узрасту и сл.", при чему подела нема коначни низ чланова, те се помињу аутомеханичарски, правнички, административни, новинарски, спортски, студентски жаргон и сл. (Бугарски, 2004a: 137). Такође, (омладински) жаргон види се и као последица социјалног раслојавања омладине (в. Кашић, 1987: 71).

Сматра се да жаргон „поштује граматику језика у коме се ствара” (Јо- 
вановић, 2011: 104), односно, како Јован Кашић (1987: 71) преноси, „жаргони 'паразитирају' на граматичком систему неког језика, не нарушавајући битно његова фонолошка, морфолошка и синтаксичка правила. Даље, Јелена Јовановић (2011: 104) истиче да „готово све жаргонске речи имају свој еквивалент у књижевном језику", при чему посебно наглашава обележје експресивности.

Од истраживања о жаргону, издвајамо монографију Р. Бугарског (2003), у којој се бавио семантичким и творбеним аспектима српског жаргона; употребом енглеских лексема у српском жаргону бавила се Н. Живковић (2011); жаргоном и жаргонским метафорама за жену и мушкарца у српском и хрватском језику бавила се Н. Пушкар (2013); о шатровачком жаргону писао је Г. Колашинац (2015); С. Филиповић Ковачевић (2018) истраживала је лексику која је у српском жаргону омладине под утицајем енглеског у клиповима јутјубера; а Д. Вељковић Станковић (2018) писала је о жаргонизмима у Речнику српскога језика Матице српске из 2011. године.

Лексикографски гледано, могући проблеми за анализу жаргонизама огледају се у томе да ли је сва лексика ексцерпирана, колико се употребљава лексика забележена у речницима (можда је у питању оказионализам), у (не)постојању писане потврде (будући да се жаргон користи у разговорном функционалном стилу), потенцијално кратком трајању неких жаргонизама, у томе да ли су регистрована сва значења која су у употреби (в. Бугарски, 2004a: 142).

За структуру конкретног речника, па и речника жаргона, важна је формална уједначеност лексикографских дефиниција лексема истог типа, попут именичких сложеница конкретног творбеног типа, изведеница од глаголске основе и истог суфикса. У вези са наведеним, Душанка Вукићевић (1997: 366) истиче: „,[П]ошто лексикограф у свом поступку настоји да се речима бави на исти начин, лексикографске дефиниције речи истог творбено[-] семантичког типа требало би, ипак, да буду уједначене и да поштују исте творбене принципе". Са друге стране, што се тиче дефинисања немотивисаних речи, Вукићевић (1997: 367) наводи да се „дефинишу описним путем, а изведенице и сложенице би требало да се дефинишу помоћу основних [мотивних] речи". Даље, Стана Ристић (2003: 120) наводи да речничку синтаксу чине „предикатно-актантни, пропозициони модели, на основу којих се успоставља системска повезаност јединица и установљују опште семантичке опозиције". У овом раду ћемо значења англицизама наведена у РЖЛП поредити са значењима одговарајућих енглеских лексема наведеним у Оксфордовом електронском речнику.

Под англицизмом Твртко Прћић (2012: 205) подразумева сваку реч „која је преузета из енглеског и интегрисана, у већој или мањој мери, у систем српског језика $[\ldots]$, при чему она не мора бити нужно енглеска по свом крајњем пореклу $[. .$.$] , свака домаћа или одомаћена реч која се у српском$ 
користи под утицајем енглеског језика”, а дели их (Прћић 2019: 220-223) на очигледне (нпр. бодибилдер, ваучер), скривене (нпр. дефинитивно, копија) и сирове (нпр. prepaid, attachment).

У лингвистичком приступу проучавању преводне еквиваленције наводи се више нивоа (в. нпр. Игњачевић 2011: 520), и то еквиваленција: 1) на нивоу речи, 2) изнад нивоа речи, 3) граматичка еквиваленција, 4) прагматичка еквиваленција. За прилагођавање на нивоу речи, зависно од тога какво семантичко прилагођавање англицизама постоји, Филиповић (1986: 180) даје следећу поделу: 1) нулта семантичка адаптација, 2) сужење броја и поља значења, 3) проширење броја и поља значења. Бројни су англицизми које млади у данашње време користе у сајбер комуникацији, за које Соња Филиповић Ковачевић (2018: 70) сматра да полако постају део стандардног српског језика.

Што се тиче односа конкретних енглеских речи и одговарајућих англицизама у српском, у овом раду бавимо се њиховом формалном и садржинском кореспондентношћу (према Прћић 2012), односно нивоима обличке и семантичке „еквиваленције”з посматраним ван реченичног контекста.

Код формалног поређења енглеског модела и српске реплике, Прћић (2012: 210-211) издваја следеће могућности:

Ф1: Реплика и модел су формално исти, при чему у српским репликама нема додатих суфикса (уп. маркетинг и marketing, пинк и pink, брокер и broker).

Ф2: Реплика и модел су формално врло слични и приликом транскрипције има разлике само у појединачним графемама (уп. ђус и јuice, серијал и serial), а разлике може бити у суфиксима и/или префиксима у енглеском и српском (уп. промоuчја и promotion, дефинитивно и definitely).

Ф3: Реплика је дужа од модела због творбене морфеме у српском и формално је слична са моделом (уп. сурфовати и surf, cmандардан и standard).

Ф4: Реплика је краћа од модела и формално је слична са њим (уп. еркондишн и air conditioning, паркинг и parking lot).

Ф5: Реплика је иста или (врло) слична са моделом, али модел у том облику не постоји (у енглеском), већ само формално садржи форманте иначе карактеристичне за енглески (рекордер према record holder, шоу-програм према show).

Ф6: Реплика и модел су формално потпуно различити, али су повезани на садржинском нивоу (уп. разлике и differences, слободан и free).

\footnotetext{
${ }^{3}$ Појам еквиваленција наводимо под наводницима јер у теорији превођења има различитих мишљења у вези са постојањем еквивалентних, односно правих синонимних, значења чак и у оквиру једног језика, а камоли између два језика (в. детаљније у Игњачевић 2011: 522).
} 
Што се тиче садржинске кореспондентности реплике и модела, Твртко Прћић (2012: 213-215) даје поделу на следећих шест нивоа:

$\mathrm{C} 1$ : Реплика и модел садржински су исти, као компјутер и computer, оба у значењу „рачунар”.

$\mathrm{C} 2$ : Реплика и модел су садржински повезани, али делимично различити, при чему реплика има специјализовано, односно уже, значење од модела, као Ђус „густи сок од поморанџе” у односу на јuісе „воћни сок".

C3: Реплика и модел су садржински повезани, али делимично различити, при чему реплика има шире значење од модела, као тајмаут „пауза у некој активности” у односу на timeout „пауза у спортској утакмици".

C4: Реплика и модел су садржински повезани, али делимично различити, при чему се између значења реплике и модела уочава метафорички или метонимијски пренос, као хорор „ужасан стваран догађај” у односу на horor „филм који приказује ужасне догађаје”.

C5: Реплика и модел су повезани, али садржински различити, значење модела и/или примарно значење реплике је модификовано, а при томе у енглеском не постоји такав модел који обједињује новодобијено значење (уп. бос „шеф групе или организације, понекад на ивици закона" и boss „шеф”, букмејкер „особа која се клади” и bookmaker „особа која прима опкладе").

C6: Реплика и модел су садржински неповезани. Наглашено је да се обично ради о значењима преузетих из неког другог (посредничког) језика, а не енглеског, у овом случају (уп. мобинг и workplace bullying, оба у значењу ,злостављање на радном месту”).

\section{3. Непромењеност значења англицизама у жаргону југоисточне Србије у односу на енглеске лексеме}

У овом одељку прокоментарисаћемо примере англицизама који у жаргону југоисточне Србије имају исто значење као у енглеском, тј. реплика и модел имају исто значење (према Прћићу 2012, тип С1), али се при томе модел и реплика формално могу разликовати у мањој или већој мери (према Прћићу 2012, могући типови су од Ф1 до Ф6, које смо представили у теоријском одељку рада). У обзир су узети и примери употребе дати у РЖЈП.

Употребљавајући англицизме код којих је задржано значење енглеске лексеме, говорник може имати већи степен сигурности да ће његов саговорник, под претпоставком да зна значење изворних енглеских речи, на правилан начин разумети поруку и да ће, самим тим, комуникација бити успешна. Међу таквим примерима у Речнику жаргонизама јужне пруге највише има 
именица и глагола, а ниво формалне сличности у односу на енглески модел варира од Ф1 до Ф5.

У групи формално истих енглеских реплика и српских модела су примери попут админ „особа која одржава интернет странице, администратор” (већ скраћено у енглеском admin од administration, ,the administration of a business, organization, etc.; the department in a company that does this"), $u н$ „модерно, тренутно актуелно” (in „fashionable, popular”), инста „друштвена мрежа инстаграм” (скраћено и неформално Insta од Instagram ,, a social media website where people can share photographs and short videos"), милф „пожељна старија женска особа” (ова лексема је и у енглеском жаргонски маркирана, али није регистрована у Оксфордовом речнику, већ наводимо на интернету доступно објашњење ,, a sexually attractive older woman, typically one who has children”), морон „глупак” (moron ,an offensive way of referring to somebody that you think is very stupid”), овер „крај” (over ,ended”), рандом „преко реда" (random, ,done, chosen, etc. without somebody deciding in advance what is going to happen, or without any regular pattern”), соло „сам” (solo „done by one person alone, without anyone helping them”), фан „обожавалац" (fan ,a person who admires somebody/something or enjoys watching or listening to somebody/something very much”), xuncmep ,,алтернативац” (hipster ,a person who follows the latest trends and fashions in clothes, music, etc., especially those that are outside the cultural mainstream").

Са постојањем англицизама увећава се број непроменљивих лексема у српском језику. Такви су из ове подгрупе ин, aфmep (енгл. in, after).

У групи Ф2, у којој се реплика и модел разликују само због транскрипције појединих графема, налазе се следећи примери у којима се задржало значење енглеских лексема: aym „није у моди” (out „,not fashionable”), гејмер „2. играч игрица на компјутеру”4 (енгл. gamer ,a person who likes playing computer games”), екстра „који је одличан, врло добро” (extra „more than is usual, expected, or than exists already”), кежуал „опуштено, који је опуштен” (casual „not formal”), инбокс „поштанско сандуче на интернету” (inbox „the place on a computer or phone where new emails, text messages, etc. are shown”), кеш „новац” (cash „2. (informal) money in any form”), кис „пољубац" (kiss ,the act of kissing somebody/something”), клабинг „2. ноћни провод по клубовима" (clubbing ,the activity of going to nightclubs regularly"), кул „1. нешто добро, лепо, занимљиво, који је добар, леп, занимљив. 2. опуштено” (cool (informal) ,4. used to show that you admire or approve of somebody/ something because they are/it is fashionable, attractive and often different. 7. calm; not excited, angry or emotional”), лузер „губитник” (loser „1. a person

\footnotetext{
4 У овом одељку наводимо само непромењена значења у односу на изворна значења одговарајућих енглеских пандана, зато је овде наведено само друго значење из РЖЈП, док ће прво бити наведено у одељку са модификованим значењима. Исто важи и за остале наведене лексеме.
} 
who is defeated in a competition. 2. (rather informal) a person who is regularly unsuccessful, especially when you have a low opinion of them. 3. a person who suffers because of a particular action, decision, etc.”), мајк „микрофон” (пун облик microphone, скраћено mike (informal), ,a device that is used for recording sounds or for making your voice louder when you are speaking or singing to an audience”), најс „лепо, који је леп” (nice „pleasant or attractive”), нуб „новајлија, неискусна особа” (nоob (informal), ,a person who takes part in an activity, usually an online video game, but lacks relevant knowledge and therefore performs badly”), селфи „самофотографисање” (selfie (informal) ,a photo of yourself that you take, typically with a smartphone or webcam, and usually put on social media”), сингл „сам, није у вези са особом супротног пола" (single „not married or having a romantic relationship with somebody"), стрејт „који је исправан (није пијан, не дрогира се, није хомосексуалац)” (straight (informal), a person who has sexual relationships with people of the opposite sex, rather than the same sex”), стокер „ухода” (stalker ,, person who follows and watches another person over a long period of time in a way that is annoying or frightening”), тинејиер ",дечак или девојчица у доба пубертета" (teenager ,a person who is between 13 and 19 years old”), фajm „туча" (fight ,a struggle against somebody/something using physical force”), фajmep „борац”, (fighter ,2. a person who fights 3. a person who does not give up hope or admit that they are defeated"), фејк „лажан” (fake „not what somebody claims it is; appearing to be something it is not"), фенси „који је леп, префињен” (fancy „expensive or connected with an expensive way of life”), фешн „модерно” (fashion ,a popular way of behaving, doing an activity, etc."), филинг „осећај” (feeling ,,something that you feel through the mind or through the senses"), флерт „кокетирање” (firt „to behave towards somebody as if you find them sexually attractive, without seriously wanting to have a relationship with them"), френд „пријатељ” (friend ,a person you know well and like, and who is not usually a member of your family”), фриц „фрижидер” (fridge, краће од формалног refrigerator ,a piece of electrical equipment in which food is kept cold so that it stays fresh”), хаj „узвик поздрава” ( $h i$ „,used to say hello”), хакер „стручњак за рачунарске системе" (hacker,,a person who uses computers to get access to data in somebody else's computer or phone system without permission"), xaoc „1. неред” (chaos ,,a complete lack of order”), хелоу „узвик при поздрављању, здраво” (hello „used as a greeting when you meet somebody, in an email, when you answer the phone or when you want to attract somebody's attention"), xejm

\footnotetext{
${ }^{5}$ За значење овог англицизма Твртко Прћић (2012: 214) наводи да се разликује од значења енглеског модела, који означава особе оба пола одређеног узраста, а у српском само особе мушког пола, што није потврђено у Речникужаргонизама јужне йруге, већ се значење везује за дечаке и девојчице.

${ }^{6}$ Друго значење овог англицизма измењено је у односу на енглеску лексему, па ћемо га коментарисати у наредном одељку.
} 
„мржња” (hate „a very strong feeling of dislike for somebody”), хепенинг није било који догађај, већ неки важан: „окупљање, важно дешавање”, при чему и у енглеском (често у множини happenings) може имати такво уже значење - „1) an event; something that happens, often something unusual, 2) an artistic performance or event that is not planned”, цанки „наркоман” (junkie „a drug addict”), цинс „фармерице” (jeans ,trousers made of denim”).

Непроменљиви англицизми у овој групи су аут, екстра, кежуал, кул, најс, сингл, стрејт, фејк, фенси, фешн, хај, хелоу. Именице на сугласник, односно нулти наставак у номинативу једнине, углавном су адаптиране као именице мушког рода и деклинирају се по првој Стевановићевој врсти, попут гејмер, кеш, кис, лузер, мајк, нуб, клабинг, стокер, тинејиер, фајт, фајтер, филинг, флерт, френд, хакер, хаос, хепенинг, цинс, али има и именица мушког рода на - $u$ које су се у парадигми такође уклопиле у први деклинациони тип, попут селфи и цанки.

Дужа реплика од модела је на нивоу формалне кореспондентности Ф3, у примерима попут именица старлета „лепа особа без професије” (starlet „a young woman actor who plays small parts and hopes to become famous") и фантазија „нешто веома добро” (fantasy ,, a pleasant situation that you imagine but that is unlikely to happen"). Још један адаптиран англицизам на - $a$ јесте мјуза за значење „музика” (у преношењу скраћене основе имамо ослањање на изговор енглеске речи тusic [мјузик]), а додатни разлог за задржавање $j$ у основи може бити хомоформичност која би без $j$ у основи настала са већ постојећом именицом муза у српском језику.

Што се тиче англицизама међу глаголима, (прво) значење углавном је исто као и у енглеском. Издвојили смо глаголе који се јављају у РЖЈП и њихова значења у енглеском према Оксфордовом речнику. Формално гледано, однос између енглеских модела и српских реплика јесте Ф3 будући да су у српском додати одговарајући глаголски суфикси, конкретно -овати, -ирати (за -исати није било потврда у нашој грађи).

Међу глаголима на -овати су следећи:

Глагол апдејтовати 7 се у РЖЈП јавља само у облику (трпног глаголског) придева апдејтован „надограђен” (update „to make something more modern by adding new parts, etc.”), даунлодовати (даунлодује) „скида датотеке са интернета" (download „to get data from another computer, usually using the internet”), искриниовати (искриниује) „осећа се непријатно” (cridge „2. to feel very embarrassed and uncomfortable about something"), синовати (синуje) „1. прегледа 2. игнорише поруку” (seen од see „1. to become aware of somebody/something by using your eyes”), сејвовати (сејвује) „чува податке” (save ,to make a computer keep data by putting a copy in a location where it will

\footnotetext{
${ }^{7}$ Глаголи су у Речнику жаргонизама јужне йруге навођени у 3. лицу једнине презента пошто инфинитив није карактеристика те дијалекатске зоне, а за потребе рада смо реконструисали инфинитиве.
} 
be stored”), спамовати (спамује) „досађује шаљући исту поруку” (spam „to send the same message to large numbers of internet users who have not requested the information”), сталковати (сталкује) „прати некога (на друштвеним мрежама)", при чему се у енглеском не издваја ухођење на друштвеним мрежама (stalk ,2. to illegally follow and watch somebody over a long period of time, in a way that is annoying or frightening"), стартовати (стартује) „1. почиње, почне” (start „to begin doing or using something”), старовати (cmapyje) „означи као битно” (star „to put a symbol with a shape like a star (= an asterisk) next to a word, etc. in order to make people notice it"), супскрајбовати (се) (супскрајбује ${ }^{8}$, „учлани се” (subscribe „2. to arrange to have regular access to an electronic information service or other internet service"), таговати (тагуje) „означава на друштвеним мрежама” (tag ,5. to add a link to various users' profiles from a photo on a social media website"), тверковати (тверкује) „врста игре и плеса" (twerk (informal) ,to dance to popular music with the body bent low and the hips moving forwards and backwards", типовати (типује) „бира, прогнозира” (tip „6. to say in advance that somebody/something will be successful”), триповати се (трипује (се)) „умисли, умишља, причињава му ce”, при чему се не наглашава узрок халуцинације (trip ,5. (informal) to be under the influence of a drug that makes you hallucinate"), ? фајтовати се био би реконструисани облик инфинитива од фajmyje ce „туче се” (fight „2. to struggle physically with somebody”), хаковати (хакуjе) „открива шифре других корисника" (hack „3. to secretly find a way of looking at and/or changing information on somebody else's computer system without permission"), xejmoвати (хејтује) у РЖЈП има значење „1. мрзи, не подноси. 2. шири мржњу” (to hate „1. to dislike somebody/something very much”), четовати (четује) има значење „дописује се преко интернета" (chat „2. to exchange messages with somebody on the internet, when you can see and reply to messages immediately and have a written conversation").

Чекирати је једини глагол на -ирати у грађи и има непромењено значење у односу на енглески модел. Наиме, значење у РЖЛП „2. погледа, уочи, запази” упоредиво је са енглеским значењем check „2. to look at something or ask somebody to find out if something/somebody is present, correct or true or if something is how you think it is". Прво жаргонско значење је модификовано и коментарисаћемо га у наредном одељку.

Међу глаголима су и они са префиксима: забаговати, убаговати, улоговати се, што показује јачу уклопљеност глагола баговати и логовати се у морфолошки систем српског језика и творбени потенцијал англицизама.

Код именица мушког рода у српском има и скраћивања ${ }^{9}$ основа из енглеског, при чему је краћа реплика од модела (Ф4) уочљива у примерима

\footnotetext{
${ }^{8}$ Са 6 је забележено у РЖЈП: субскрајбује.

${ }^{9}$ Сличне примере скраћивања основе наводи Јован Кашић (1987: 73): ӣреф уместо йреферанс, Ђава уместо Петироварадинска ивврава, мјуз уместо енглеског изговора „мјузик” за тиsic.
} 
фejc „фејсбук” (скраћено од Facebook „,a very popular social media website”), комп „компјутер”, нет „интернет”, моб „мобилни телефон”, где је у претходним примерима на крају нулта морфема (односно нулти наставак: -Ø), флеш „флеш-меморија” (flash drive „, s small memory device that can be used to store data from a computer or digital camera and to move it from one device to another").

Нивоу Ф5, који у реплици садржи творбене форманте који подсећају на оне које постоје у инвентару језика са кога се преводи, али не постоји у конкретном моделу - припадају следеће лексеме: мултитаскер „особа која истовремено ради више радњи" (у енглеском не постоји multitasker, накнадно је у српском додат суфикс -ер, а глагол multitask значи „1. to operate several programs at the same time. 2. to do several things at the same time"), зaтим тенисер, а у енглеском tennis player, не tenniser. Cmрејтер је особа без порока, хејтер „1. особа која мрзи све око себе. 2. особа која се не уклапа”, репер „извођач реп музике”, аналошки је суфиксом -ер у српском добијено кулер у значењу nomina agentis (не у значењу предмета), односно у значењу „опуштена особа" - онај који кулира.

Творба адаптираних англицизама врши се првенствено српским жаргонски немаркираним суфиксима (јављају се и у стандардном српском језику, нису везани само за жаргон). Међу њима су суфикси који (иначе) доприносе пејоративном/аугментативном значењу - -чина (гејчина ${ }^{10}$ „хомосексуалац”); са моционом функцијом -ка (клаберка „девојка која често посећује журке или излази у клубове”, фенсерка „женска особа која прати модне трендове”, тичерка „професорица енглеског језика”), -ица (френдица „пријатељица"); значењем предмета, као у именицама са суфиксом -ка које cy pluralia tantum (левиске „панталоне марке 'Левис'”, скејтерке „широке патике, углавном их носе они који возе скејтборд”); граматички суфикс за глаголске именице -je/-ње (хејтовање „мржња”) и суфикс страног порекла -ер за значење nomina agentis (кулер „опуштена особа”). Друга могућност је творба жаргонски маркираним суфиксима, односно оним карактеристичним за разговорни функционални стил (а не онима који се уобичајено јављају при деривацији у стандардном српском језику), видљива у следећим примерима, разврстаним према суфиксима: -иша (стајлиша „особа која се модерно облачи”), -уша (флертуша „девојка склона флерту”), -иш (компиш „компјутер”), -ос (кримос „криминалац”, лезбос „лезбејка”). Сливеница попут њамбургер „хамбургер” (од њам и хамбургер) такође су карактеристика жаргона (о тзв. лексичким скривалицама в. Бугарски 2003).

Квантитативни однос између различитих нивоа формалне кореспондентности англицизмима код којих се у жаргону југоисточне Србије задржало значење енглеских лексема иде у корист нивоа Ф2 (44,87\%) и Ф3 (28,2\%), затим следи ниво Ф1 (12,82\%), а занемарљив је проценат примера за нивое

${ }^{10}$ Лексема геј није забележена у РЖЈП. 
Ф5 (7,69\%) и Ф4 (6,41\%). Ови подаци показују да је у 44,87\% случајева адаптација англицизама фонолошка (према изговору), морфолошка адаптација је у 28,2\% случајева (додавањем одговарајућих морфема), у 12,82\% случајева англицизми су формално исти као одговарајуће енглеске речи. Затим, у 7,69\% случајева творбени модели изгледају као енглеске речи, али су творбени форманти налик енглеским додати у српском, док је ретко скраћивање облика енглеских речи (6,41\%).

Будући да у жаргонским англицизмима анализираним у овом одељку постоји потпуна садржинска кореспондентност са одговарајућим енглеским моделима, однос форме и садржине је процентуално следећи: у 57,69\% случајева постоје прави формално-садржински парови (укрштање садржинског нивоа C1 и формалних Ф1 или Ф2), а лажни формални парови у 42,3\% случајева (укрштање садржинског нивоа С1 и формалних нивоа Ф3, Ф4 или $\Phi 5)$.

\section{4. Модификовање значења англицизама у жаргону југоисточне Србије}

У овом одељку бавићемо се модификацијом значења код једнозначних и вишезначних англицизама ексцерпираних из Речника жаргонизама јужне пруге (било да је само једно значење модификовано, било да је више значења семантички модификовано). Кореспондентност модификованих значења између енглеских модела и српских реплика посматраћемо на основу поделе Твртка Прћића (2012) на нивое које смо увели у теоријском одељку рада, и то у овом поглављу од С2 до С6, имајући у виду формалну кореспондентност код ових примера (Ф1-Ф6) и међуоднос формалне и садржинске кореспондентности.

\section{1. Једнозначни примери}

Што се садржинске кореспондентности тиче, у групи С2 су они примери код којих српска реплика има специјализовано, односно уже, значење у односу на енглески модел.

Сужавање значења уочавамо код глагола драјва се „вози се аутобусом”, који не означава само процес вожења, него и спецификује превозно средство (уп. drive „, to operate a vehicle so that it goes in a particular direction”), стајлинг у жаргону југоисточне Србије значи „изглед, одевна комбинација”, при чему је значење сужено само на изглед човека, конкретно на његову одећу, у односу на значење у енглеском „начин на који је нешто осмишљено” (styling „2. the way in which something is designed”), тичер „професор (или професорица) енглеског језика" има општије значење у енглеском јер се односи на сваког учитеља/наставника, без ограничења предмета који предаје (teacher 
„a person whose job is teaching, especially in a school”), спојлери „сало на боковима које се прелива преко панталона" имају у жаргону југоисточне Србије врло спецификовано значење у односу на четврто значење вишезначне енглеске речи spoiler „4. a person or thing that intends or is intended to stop somebody/something being successful"). У свим до сада наведеним примерима је формална кореспондентност енглеских модела и српских реплика на нивоу Ф2, односно има прилагођавања енглеских графема.

Нема примера англицизама који имају проширено значење у жаргону без метафоричких и метонимијских преноса значења (C3), али има примера за ниво C4, у коме значење реплике садржи метафоричке или метонимијске преносе, које ћемо детаљније коментарисати у наставку.

По пореклу придев, а у српском жаргону у именичкој употреби, анонимус се у РЖЛП јавља у значењу „непозната, небитна особа” (anonymous „1. with a name that is not known or that is not made public"), при чему је наглашено да се може радити о небитној особи, којој као да се не зна име. Метафорички преноси чести су процеси за добијање нових значења како у савременом српском језику тако и у жаргону. На тај начин су, између осталог, добијена нова значења у српском жаргону. На пример, тренер има значење „разредни старешина” јер ,тренира”, усмерава одељење и решава проблеме ученика (trainer ,2. a person who teaches people or animals to perform a particular job or skill well, or to do a particular sport"), а у српском језику степен прилагођености потврђује моциони облик тренерка „женска особа разредни старешина”. Затим, према карактеристичној особини предмета/особе/појаве именује се други предмет или друга особа/појава. Тако је у РЖЛП компјутер „ученик који све зна”, а пренос значења огледа се у томе да компјутер може складиштити и обрадити велику количину информација (уп. сотрuter, an electronic machine that can store, organize and find information, do processes with numbers and other data, and control other machines”). Матрикс је „математика”, при чему се наглашава сложеност/ тежина овог предмета, каква је и матрица типично по структури (matrix ,an arrangement of numbers, symbols, etc. in rows and columns, treated as a single quantity”). У синонимним значењима ,глупак” и „глуп човек” у РЖЛП наводе се телетабис (Teletubbies, ,a popular British television series for young children that started in 1997. Its main characters are Tinky Winky, Dipsy, LaaLaa and Po, four large creatures covered in coloured fur, with television screens on their stomachs, who talk a simple language like that of very young children") и бот (bot ,3. a computer program that creates fake social media accounts and communicates with other users").

Због његове изражене величине и тежине, тенком се у РЖЈП именује „дебела особа" (tank,,3. a military vehicle covered with strong metal and armed with guns. It can travel over very rough ground using wheels that move inside metal belts"). Према функцији скенера да преноси скенирану слику у цели- 
ни, скенером се именује „особа која све пажљиво прати” и стога може да пренесе све што је видела (scanner ,1. a device for examining something or recording something using light, sound or X-rays”), а фактором „особа која је поштована", односно значајна, као што сваки исход зависи од неког конкретног фактора (factor „1. one of several things that cause or influence something”).

Због тога што неисправан аутомобил не може да се вози, направљен је од сличног материјала као контејнер и непривлачног је изгледа, управо се контејнером у РЖЛП назива „велики и неисправан аутомобил” (container „1. a box, bottle, etc. in which something can be stored or transported”). Напомињемо да је и у стандардном српском значење лексеме контејнер различито од изворног енглеског значења „садржалац, посуда”, а да се метафорички пренос догодио у односу на значење „велика канта за отпатке”.

У РЖЛП „дуга, неуредна коса” назива се цунглом (jungle „1. an area of tropical forest where trees and plants grow very thickly"). Слична повезаност по облику, односно визуелним карактеристикама, уочава се када се „пиво у пластичној флаши од 2 литра” назива торпедо (torpedo ,a long, narrow bomb that is fired under the water from a ship or submarine and that explodes when it hits a ship, etc.”). Такође, у РЖЛП „силиконска футролица, заштита за телефон” именује се лексемом кондом (condom „1. a thin rubber tube that a man wears over his penis during sex to stop a woman from becoming pregnant or to protect against disease"), при чему постоји метафорички пренос по функцији коју има и начину употребе (обмотавање и заштита). Метафорички пренос по облику постоји у жаргонски употребљеним лексемама монокл „модрица око очне јабучице", при чему је од значаја и место на коме се носи монокл и на коме се јавља модрица која се овако назива (monocle, ,a single glass lens for one eye, held in place by the muscles around the eye and used by people in the past to help them see clearly"), и оскар ,,јединица као оцена" јер Оскар визуелно подсећа на јединицу због изражене димензије висине (Oscar ,one of the awards given every year by the US Academy of Motion Picture Arts and Sciences for achievement in the making of films").

При поређењу значења реплике и модела код лексеме аплауз „шамар, ударац по лицу" (applause ,the noise made by a group of people clapping their hands and sometimes shouting to show their approval or pleasure") уочава се метонимијски пренос значења јер се руке користе за обе радње (аплаудирање и ударање).

Што се тиче формалне кореспондентности модела и реплика у овој по групи примера, у примерима бот и торпедо је Ф1 ниво, а у свим осталим примерима формална кореспондентност је $\Phi 2$.

Значење реплике супротно је значењу модела (C5) код придева криминалан „који је интересантан, духовит, интелигентан, забаван” будући да у РЖЛП нема негативну конотацију и њиме се означава супротан крај значењске скале - нешто што је добро у различитим сферама, односно неш- 
то што је занимљиво, духовито, интелигентно и забавно (уп. criminal „1. connected with or involving crime. 2 . connected to the laws that deal with crime. 3. morally wrong”). Формална кореспондентност ове реплике у односу на енглески модел је Ф3.

Реплика и модел су садржински неповезани (C6) у наредна два примера: трипер је „особа која је нешто уобразила”, односно која трипује, (уп. tripper ,a person who is visiting a place for a short time for pleasure") и тилтује ce „нервира се” (уп. tilt ,1. to move, or make something move, into a position with one side or end higher than the other. 2. to make something/somebody change slightly so that one particular opinion, person, etc. is preferred or more likely to succeed than another; to change in this way"). Ниво формалне кореспондентности је у овим примерима Ф5 и Ф3.

У групи једнозначних англицизама у жаргону југоисточне Србије чије се значење модификовало у односу на енглеске моделе, 70,83\% англицизама има садржински спецификовало значење помоћу метафоричних и метонимијских преноса. Што се тиче формалне кореспондентности, доминира фонолошка адаптација енглеских графема (Ф2) 79,17\%.

\section{2. Вишезначни примери}

Посматрајући ексцерпирану жаргонску грађу из Речника жаргонизама јужне пруге, увидели смо тенденцију ка моносемичности англицизама. Малобројне полисемичне англицизме са (бар једним) модификованим значењем у односу на енглеске моделе прокоментарисаћемо у наставку.

Сужење/спецификовање значења српске реплике у односу на енглески модел (C2) уочава се у наредним примерима:

Лексема акиија у РЖЈП има два значења „1. дружење, журка. 2. криминална незаконита активност", оба сужена у односу на значења у енглеском (action ,1. the process of doing something in order to make something happen or to deal with a situation").

За лексему фул (full) „1. веома добро, онако како треба, који је комплетан. 2. (у изразу „у фулу”) комплетно, потпуно, целокупно” у РЖЛП су у оквиру првог значења обједињена различита значења, дакле, могли су бити издвојена значења „веома добро”, „онако како треба” (full ,adv. directly”) и значење „који је комплетан”, односно целовит, које постоји у енглеском и није синонимно са претходнонаведеним жаргонским значењима (full ,adj. 4. complete; with nothing missing”). Још један разлог за издвајање поменутих лексикографских одредница јесте тај што су прва два значења прилошка, а треће је, према формулацији, придевско. Сматрамо да није било неопходно издвајање значења предлошко-падежног споја у фулу, јер је у директној вези са већ наведеним значењем комплетности/потпуности.

Глагол стартовати (стартује) у РЖЛП има два значења „1. почиње, почне. 2. удвара се”, при чему је прво преузето из енглеског (start „, to begin 
doing or using something"), није модификовано и већ смо га коментарисали, али није регистровано значење које се тиче (почињања) удварања, што је модификовано значење. За лексему чекирати уочава се сужено значење „1. означи локацију на друштвеним мрежама” у односу на енглеско check ,3. to put a mark $(\checkmark)$ next to an item on a list, an answer, etc." будући да се везује само за друштвене мреже.

Лексема афтер у РЖЛП обухвата два значења „вече после провода, после". Значење које се односи конкретно на вече после провода је сужено (уп. after „later in time, afterwards").

Што се тиче нивоа формалне кореспондентности наведених лексема, нивоу Ф2 припадају акиија и фул, стартовати и чекирати нивоу Ф3, а афтер нивоу Ф1.

Проширење значења (C3) реплике у односу на модел у ексцерпираној грађи потврђено је у примеру гејмер „1. играч уопште” (енгл. gamer „а person who likes playing computer games"), при чему гејмер припада нивоу Ф2 формалне кореспондентности. Још више је примера за метафоричке/ метонимијске преносе значења реплике у односу на модел (C4), које наводимо у наставку. За лексему клабинг у жаргону постоји значење „1. клуб”, које се разликује од значења енглеског модела clubbing ,the activity of going to nightclubs regularly" (напомињемо да је и то значење потврђено у жаргону „2. ноћни провод по клубовима” и коментарисано је у одељку о непромењеним значењима англицизама у односу на енглеске лексеме). У овом примеру постоји метонимијска повезаност клуба и активности (редовног) одласка у ноћне клубове. Именица фудбалерка „мушка фризура са завезаним репом" изведена је суфиксом -ка и односи се на фризуру која је популарна код фудбалера (уп. football player haircut). Значење глагола кулирати (кyлира) „2. избегава, игнорише” може се метафорички повезати са значењем из енглеског ( $\mathrm{cool}$,to become calmer, less excited or less enthusiastic") у смислу да особа која кулира неког постаје хладна према њему. Овде припада и лексема хејтовати (хејтује) у значењу „3. налази ману” (to hate „1. to dislike somebody/something very much"). Формално су у питању ниво Ф2 (први пример) и Ф3 (други, трећи и четврти пример).

У групи С5 садржинске кореспондентности су парови реплике и модела код којих постоји супротно или асоцијативно повезано значење, какав је наредни пример из наше грађе. Лексема $х а о с$ је у РЖЛП издвојена у значењу карактеристичном за жаргон „,2. нешто веома добро”, које је супротно значењу које се јавља у стандардном српском језику и у енглеском моделу (chaos ,,a complete lack of order”). Формална кореспондентност је Ф2.

Садржински су модел и реплика неповезани (С6) у примеру баговати (багује) „1. збуни се. 2. кочи се. 3. греши” и не могу се довести у везу са значењем енглеског модела (bug „1. to put a special device (= a bug) somewhere in order to listen secretly to other people's conversations. 2. (informal) to annoy 
somebody”), кулирати (кулира) „1. одмара. 3. дружи се са блиском особом” (cool ,to become calmer, less excited or less enthusiastic”). За глагол искулирати (искулира) у РЖЛП постоји и значење неповезано са значењем поменутог енглеског модела: „2. зна веома мало, онолико колико је довољно за најнижу оцену”. Изведеница суфиксом -ара комплетара „лепиња са свим прилозима" није у директној семантичкој вези са већ помињаном енглеском лексемом complete. Формална кореспондентност је у свим примерима Ф3.

Мали је број примера за детаљнију анализу модификације значења, а само је један пример ширења, уопштавања значења. Да поновимо, садржинском С2 односу између реплике и модела припада 5 примера, од чега 2 припадају формалном нивоу Ф2, 2 нивоу Ф3, а 1 нивоу Ф1; С3 нивоу припада један пример на Ф2 нивоу. Затим, ниво С4 има 4 примера, један за Ф2 и три за Ф3 ниво; С5 нивоу припада један пример, на Ф2 нивоу; док ниво С6 има 4 примера и сви они су Ф3 ниво.

Сви примери у овом одељку су формално-садржински лажни парови.

\section{5. Закључак}

У овоме раду бавили смо се англицизмима у жаргону југоисточне Сpбије на примерима ексцерпираним из Речника жаргонизама јужне пруге поредећи их притом са енглеским еквивалентима и њиховим значењима наведеним у Оксфордовом електронском речнику. Грађу доминантно чине именице, глаголи и придеви, којима смо приступили из угла семантичког/ садржинског и морфолошког/формалног/обличког односа енглеских модела и српских реплика према типологији Твртка Прћића (2012). Напомињемо да ексцерпирани англицизми анализирани у овом раду припадају жаргонским подсистемима попут школе (примери жаргонизама су оскар, матрикс), рачунарске терминологије у ширем смислу (чекирати, гејмер), предмета у свакодневној употреби (попут фриц, контејнер), именовања људи и предмета са одређеним карактеристикама (цунгла, монокл, фул, фејк и сл.).

Посматрајући ексцерпиране англицизме из Речника жаргонизама јужне пруге, увидели смо тенденцију ка моносемичности англицизама. Прецизније, однос англицизама са непромењеним и модификованим значењем у Речнику жаргонизама јужне пруге износи 69\% према 31\%, што у две трећине случајева показује тенденцију задржавања изворног значења из енглеског језика у жаргону југоисточне Србије. Прва група англицизама су они који су у жаргону задржали исто значење које имају у енглеском попут фан „обожавалац”, хејт „мржња” (C1 ниво). Са друге стране су лексеме енглеског порекла са модификованим значењем у жаргону југоисточне Сpбије, и то на више потврђених нивоа: С2 (тичер ,професор (или професорица) енглеског језика”, драјва се „вози се аутобусом” итд.), С4 (монокл „мод- 
рица око очне јабучице”, матрикс „математика”), С5 (криминалан „који је интересантан, духовит, интелигентан, забаван”, хаос „нешто веома добро” итд.), С6 (mpипер „особа која је нешто уобразила”, комплетара „лепиња са свим прилозима" итд.). Код модификованих значења англицизама уочили тенденцију сужавања/спецификовања значења у односу на енглеске моделе, а формално су транскрибовани уз неопходна мењања графема или додавања одговарајућих суфикса.

Модел и реплика на формалном су плану у највећем броју случајева исти (нпр. fan-фpaн), што је, према Прћићевој подели, Ф1 ниво. Има и примера за ниво Ф2, при чему је разлика у писању фонема (уп. fridge-фpuи). Даље, постоје примери за Ф3 ниво, при чему је реплика дужа од модела (уп. fantasy-фантазија, starlet-cmaрлета), што је карактеристично и за све глаголе, попут старовати, стартовати, таговати (уп. енгл. star, start, tag). Потврђено је и скраћивање реплике у односу на модел (Ф4), у примерима попут комn, нет, моб итд. (уп. енгл. computer, Internet, mobile phone). Са друге стране су англицизми формалне кореспондентности Ф5, при чему творбени форманти који се јављају у англицизму иначе постоје у енглеском, али не у тим конкретним лексемама, што потврђују лексеме мултитаскер, стрејтер, репер итд., које у енглеском немају еквиваленте у облицима multitasker, straighter, rapper и сл.

Квантитативни однос између различитих нивоа формалне кореспондентности англицизмима код којих се у жаргону југоисточне Србије задржало значење енглеских лексема показује да је у 44,87\% случајева адаптација англицизама фонолошка, морфолошка адаптација је у 28,2\% случајева, у $12,82 \%$ случајева англицизми су формално исти као одговарајуће енглеске речи. У 7,69\% случајева творбени типови су исти као код енглеских речи, али су творбени форманти налик енглеским додати у српском, док је ретко скраћивање облика енглеских речи (6,41\%). Другим речима, код англицизама које карактерише садржинска кореспондентност са одговарајућим енглеским моделима, однос форме и садржине је процентуално следећи: у $57,69 \%$ случајева постоје прави формално-садржински парови (укрштање садржинског нивоа С1 и формалних Ф1 или Ф2), а лажни формални парови у 42,3\% случајева (укрштање садржинског нивоа С1 и формалних Ф3, Ф4 или Ф5).

Са друге стране, у групи једнозначних англицизама у жаргону чије се значење модификовало у односу на енглеске моделе, 70,83\% англицизама је садржински спецификовало значење помоћу метафоричних и метонимијских преноса. Што се тиче формалне кореспондентности, доминира фонолошка адаптација енглеских графема (Ф2) у 79,17\% англицизама из ове групе.

Творба адаптираних англицизама врши се првенствено српским немаркираним суфиксима. Међу њима су пејоративно/аугментативно обележени суфикс 
-чина (гејчина); суфикси -ка (клаберка, фенсерка, тичерка) и -ица (френдицуа) са моционом функцијом; суфикс -ка који се јавља у изведеницама са значењем предмета, као у именицама pluralia tantum левиске, скејтерке; граматички суфикс за глаголске именице -је/-юе (хејтовање), суфикси -уша (флертуша) и суфикс страног порекла -ер за (кулер) у наведеним именицама nomina agentis. Друга могућност је творба жаргонски маркираним суфиксима, односно оним карактеристичним за разговорни функционални стил (а не онима који се уобичајено јављају при деривацији у стандардном српском језику). Такви су следећи суфикси: -има (стајлиша), -им (компиш), -ос (кримос, лезбос). Сливенице попут юамбургер (од њам и хамбургер) такође су карактеристика жаргона.

\section{Литература}

Бугарски, 2003: Р. Бугарски, Жаргон, Београд: Библиотека XX век.

Бугарски, 2004a: Р. Бугарски, Жаргонски изазови лексикографији, Научни састанак слависта у Вукове дане, 32/1, 137-146.

Бугарски, 2004б: Р. Бугарски, Српски жаргон између лексикона, граматике и стила, Научни састанак слависта у Вукове дане, 33/1, 81-87.

Вељковић Станковић, 2018: Д. Вељковић Станковић, О жаргонизмима у Речнику српскога језика Матице српске (2011), Српска лексикографија - речници српског језика као изворишта граматичких и семантичких истраживања, НССВД, 47, 343-354.

Вукићевић 1997: Д. Вукићевић, О лексикографској дефиницији именичких сложеница у речницима српског језика, Научни састанак слависта у Вукове дане, 26/2, 365-371.

Живковић, 2011: Н. Живковић, Употреба лексема из енглеског језика у жаргонизмима у српском језику, Савремена проучавања језика и књижевности II, књ. 1, Крагујевац: ФИЛУМ, 163-168.

Игњачевић, 2011: A. Ignjačević, Prevodna ekvivalencija: pristup, strategije i metode, Jezik struke: izazovi i perspektive, Beograd: Društvo za strane jezike i književnosti Srbije, 219-228.

Јовановић, 2011: Ј. Јовановић, О колоквијализмима и жаргонизмима у језику српске штампе, Два века савременог српског књижевног језика 1, Научни састанак слависта у Вукове дане, 40/1, 99-113.

Кашић, 1987: J. Кашић. Продуктивна морфолошка средства у жаргону, Научни састанак слависта у Вукове дане, 66/1, 71-74.

Колашинац, 2015: Г. Колашинац, Шатровачки жаргон, Багдала, год. 57, бр. 504, 101-109.

Прћић, 2012: Т. Прћић. 2012. Како се на енглеском каже олдтајмер?: англицизми као српско-енглески лажни парови, Зборник Матице српске за филологију и лингвистику, 55/2, 203-220. 
Прћић, 2019: T. Prćić, Engleski u srpskom, elektronsko izdanje, Novi Sad: Filozofski fakultet.

Пушкар, 2013: N. Puškar, O žargonu i žargonskim metaforama za ženu i muškarca u srpskom i hrvatskom jeziku, Slavenski jezici u usporedbi s hrvatskim, 3, 121-129.

Ристић, 2003: С. Ристић, Лексикографски метајезик и српска дескриптивна лексикографија, Актуелна питања проучавања, нормирања и наставе српског језика, 1, 119-130.

Филиповић Ковачевић, 2018: S. Filipović Kovačević, Leksika u srpskom jeziku pod uticajem engleskog u žargonu omladine u klipovima jutjubera Jaserštajna, Godišnjak Filozofskog fakulteta u Novom Sadu, XLIII/1, 69-81.

Филиповић, 1986: R. Filipović, Teorija jezika u kontaktu: uvod u lingvistiku jezičnih dodira, Zagreb: JAZU, Školska knjiga.

\section{Извори}

РЖЈП: Ј. Марковић, Т. Трајковић. 2018. Речник жаргонизама јужне пруге, Ниш: Филозофски факултет у Нишу.

OP: Oxford Learner's Dictionaries <https://www.oxfordlearnersdictionaries.com>

Aleksandra A. Janić

\section{ANGLICISMS IN THE JARGON OF THE SOUTHEASTERN SERBIA}

\section{Summary}

The subject of this paper is mainly semantic and formal comparison of the anglicisms in the jargon of the Southeastern Serbia with the corresponding English lexemes. The analyzed Serbian lexemes are from the Dictionary of the jargonisms of the Southeastern Serbia and the aim is to examine 1) how much the meanings of anglicisms changed in jargon; 2) to what extent are analyzed anglicisms fitted into the morphological system of Serbian. One group of the analyzed anglicisms has the same meanings as the corresponding English lexemes (fan, fejk, hejt, fensi, etc.). On the other hand, there are English lexemes which meanings are different in the jargon of the Southeastern Serbia: kontejner 'big and broken car', oskar 'the grade F', monokl 'a bruise around an eye', matriks 'mathematics', etc. The tendency for the word formation of anglicisms is also important to show the behaviour of adapted anglicisms (e.g. iskulirati, zabagovati). 